\title{
Regional Maritime Cooperation in Maintaining Maritime Security and Stability: A Test Case for ASEAN Unity and Centrality
}

Angel Damayanti
Christian University of Indonesia, Indonesia

\begin{abstract}
Southeast and East Asian regions have emerged as global strategic waters. $Y e t$, the seas in the regions remain vulnerable with overlapping claims on sea borders, piracy attacks, and other transnational challenges at sea. For these purposes, some major powers in the region, such as the U.S., China, and Indonesia, have launched their respective strategies in securing the maritime areas for their interests. To harmonize these various interests, ASEAN with its counterparts in the East Asian region needs an ASEANled, inclusive, and comprehensive regional maritime mechanism and strategic partnership between ASEAN member states and its dialogue partners to maintain good order at sea. In November 2015, the East Asian Summit eventually launched a joint Statement on Enhancing Regional Maritime Cooperation to justify the centrality of ASEAN and to counter the failure of ASEAN Defence Minister Meeting. In such case, ASEAN member states need to manage their disunity to minimize hindrances of the realization and implementation of the plan. This paper mainly elaborates the reasons why the region needs regional maritime cooperation and discusses challenges that ASEAN has to deal with in order to implement the ASEAN unity and centrality in promoting maritime cooperation and regional stability. To explain the maritime strategies of ASEAN and its dialogue partners, this study uses qualitative methods and utilizes states' documents as well as ASEAN statements particularly on maritime issues.
\end{abstract}

Key words: ASEAN, maritime security, maritime cooperation, regional stability 


\section{Introduction}

Globalization depends on the free trade system that relies on the secure and free flow of goods on sea-based shipping. The seas are therefore essential and become symbol of globalization for goods to be distributed, sold, and consumed worldwide. Moreover, international shipping underpins the prospect of further beneficial growth in economic and world trade. But to have that effect, it needs to be predictable, traceable, compliant with detailed pick and delivery schedules, stable, and secure (Till, 2009). Having said that, the emergence of Southeast and East Asian regions as the strategic center of maritime transport is also associated with an increasing numbers of both traditional and nontraditional threats, which particularly happen at sea (Prabhakar, 2006). For this reason, some countries in the regions, such as China and Indonesia, have published their respective initiatives to secure and maintain the stability of their sea territories. This is in addition to U.S. Rebalancing Strategy in Asia-Pacific launched in 2011, which is mainly aimed to secure the U.S. access in passing through the Strait of Malacca and South China Sea (Bradford, 2011; The White House, 2011; U.S. DoD, 2012).

To respond the U.S. strategy, in September 2013 Chinese President Xi Jinping initially introduced the Silk Road Economic Belt concept, followed by the initiative to build a close and strategic cooperation between China and ASEAN Community, particularly in maritime cooperation ( $X i, 2014)$. This is important as China proposes the construction of a $21^{\text {st }}$ Century Maritime Silk Road to promote regional interconnectivity and economic integration (Xinhua, 2015). A year later, in front of ten ASEAN member states and its counterparts - namely China, the U.S., Japan, India, South Korea, and Australia - Indonesian President Joko Widodo (Jokowi) launched the idea of making Indonesia as the Global Maritime Fulcrum. Jokowi's doctrine is mainly derived from the idea that the geoeconomic and geo-political world is shifting from the West to the East and with the strategic position of Indonesia, the role of Indonesian seas will be important (Widodo, 2015).

To harmonize the abovementioned strategic maritime policies, this paper accordingly supports an ASEAN-led, inclusive and comprehensive maritime cooperation between ASEAN member states with its counterparts, mainly the U.S. and China, that has been initiated in November 2015 East Asia Summit in Kuala Lumpur, Malaysia. "Inclusive" means that this partnership should be open and give opportunities to all states in Southeast and East Asian regions to become strategic partners and enjoy mutual benefit in all seas and oceans in the region. Whereas, "comprehensive" means that this maritime cooperation aims to resolve traditional threats related to sea management as well as to counter nontraditional challenges that mainly happen at sea, such as transnational organized crimes and natural disaster. Such cooperative mechanism is vital as Southeast and East Asian countries mainly have common concerns to protect their seas and to enjoy benefits from them without harming other states' interests.

Therefore, this paper also elaborates the role of ASEAN, as the institution has become a primary driving force that is responsible to maintain peace, prosperity, security, and stability, particularly in Southeast and East Asian 
regions. However, the disunity amongst ASEAN member states - as has happened in ASEAN summit in Phnom Penh, July 2012 due to the issue of South China Sea management and due to China's economic and military support towards some ASEAN members on one hand and the U.S. support on the other hand - is likely to hamper the initiative and the implementation of such maritime cooperation. Therefore, ASEAN needs to initially enhance the unity amongst its member states by fostering cooperation through regional mechanism and ensuring that cooperation on bilateral basis does no harm to other member states.

To deeply understand the issues, this paper conducts qualitative methodology, particularly the case study approach, as it allows us to see certain phenomenon not in a single event but always linked to other phenomenon. The method often involves interaction effects among many structural and agent-based variables, path dependencies, and strategic interaction among large numbers of actors across multiple levels of analysis with private information and strong incentives to bluff or deceive other actors. (Bennet \& Elman, 2006-2007; Mahoney \& Goertz, 2006). Therefore, to understand the logic behind certain maritime strategy of several states, this paper utilizes their white papers, their leaders' speech, as well as other policies and analyzes their behaviors from those materials. This paper is divided into four parts: introduction, the significances of regional maritime cooperation, the role of ASEAN and how the association unites its member states, and eventually conclusion with recommendations.

\section{The Significances of Regional Maritime Cooperation}

W. Lawrence S. Prabhakar (2006) confirms in his article "Maritime Strategic Trends in the Asia-Pacific: Issues and Challenges" that the Asia-Pacific region is a globalized maritime environment. His idea implies that in the last decades AsiaPacific region has emerged as a global strategic maritime area. Nevertheless, the region and its seas are also vulnerable from both traditional and non-traditional threats. This part accordingly explains at least three notions to confirm the significance of the region and its maritime area that accordingly calls the Southeast and East Asian states for an open and comprehensive collaboration on maritime management.

First, the Asia-Pacific waters, covering the western part of Pacific Ocean specifically Strait of Malacca as well as the East and South China Sea, have an abundant inventory of natural resources that is surely advantageous for the island countries. However, this situation is also vulnerable at the same time as a significant number of transnational organized crimes happen in the region, particularly at sea. Second, the need to protect the maritime resources and the sea lines of communication (SLOCs) in the Indo-Pacific Ocean, along with the increase of national economic prosperity, has encouraged some states to modernize their navies. However, this situation in turn provokes security dilemma ${ }^{1}$ and

${ }^{1}$ Charles W. Kegley and E. Wittkopf in their book World Politics Trend and Transformation (2001) define security dilemma as "the central problem faced by all sovereign states in an anarchic global system in which a state's arming for ostensibly defensive purposes provokes other states to arm in response, with the result that the national security of all 
creates instability in the region. Eventually, there are common concerns amongst Asia-Pacific states on their national economic development as well as regional and global stability and security maintenance materialized in their maritime strategic policies. Accordingly, Asia-Pacific states need a joint mechanism to arrange and harmonize their interests.

With regards to the abundance of oil and gas in South China Sea, there are some assumptions and estimation on the numbers of undiscovered oil and gas resources, confirming the richness of western part of Pacific Ocean. In 2010, for example, the U.S. Geological Survey (USGS) estimated that the South China Sea might contain anywhere between 5 and 22 billion barrels of oil and between 70 and 290 trillion cubic feet of gas. The Chinese National Offshore Oil Company (CNOOC) was more optimistic to estimate the potential resources in South China Sea. Using their own research project, in November 2012, they estimated that the area held around 125 billion barrels of oil and 500 trillion cubic feet of natural gas. Moreover, in 2013 the U.S. Energy Information Administration (EIA) launched an estimation of approximately 11 billion barrels of oil reserves and 190 trillion cubic feet of natural gas reserves in the area (U.S. EIA, 2013).

In addition to oil and gas reserves under the sea, the abundance of fish and other marine resources in the South China Sea certainly benefits states that are located nearby the sea. In 2010, for example, China's total aquatic production reached more than 60 million tons from its Economic Exclusive Zone (EEZ). The

declines as their armaments increase." See also Robert Jervis (1976), Perception and Misperception in International Politics, Princeton University Press. production significantly increased from 7.5 million tons in 1999, and 47.5 million tons in 2004 (FAO Fisheries \& Aquaculture, 2011). The number increases every year, as in 2015 Chinese fisheries production reached 65.2 million tons and more than 14 million tons aquatic plants captured from its maritime areas (FAO Fisheries \& Aquaculture, 2017). From the table below, we can see the massive South and East China Sea marine production that benefits the Southeast and East Asian countries.

With its EEZ covering the Strait of Malacca and the southern part of South China Sea, Indonesia gained more than 10 million tons of fisheries and more than 11 million tons of aquatic plants in 2015. This captures made Indonesia became the second biggest country enjoying the benefits from South China Sea fisheries resources after China. Vietnam also enjoyed the massive South China Sea marine production as it gained more than 6 million tons of fisheries, both captured and aquaculture fisheries. The Philippines gained nearly 3 million tons for fisheries and more than 1.5 million tons for aquatic plants, while Thailand gained nearly 3 million tons of fisheries. The massive production of South China Sea undoubtedly becomes an endowment for countries located nearby the waters.

With a proper management, maritime countries will enjoy economic development from their waters. However, the abundance of marine production may trigger illegal, unreported, and unregulated fishing and other transnational organized crimes threatening any island countries that lack control and are weak at protecting their waters and its marine resources. According to the Indonesian Ministry of Maritime Affairs and Fisheries, Indonesia 
lost about US $\$ 23$ million per year due to illegal fishing (Politik Indonesia, 2015). In order to protect its marine production and perform deterrence from illegal fishing vessels, the current Indonesian Ministry for Maritime Affairs and Fisheries under leadership of Minister Susi Pudjiastuti has firmly arrested more than 35 vessels with Chinese, Vietnamese, and Philippines flags by September 2015 (CNN Indonesia, 2014). However, this robust policy has become a concern for the Chinese, Vietnamese, and the Philippines governments and forced them to settle negotiation with the Indonesian government accordingly.

Table 1. Southeast and East Asia Fisheries and Aquatic Plants Production, 2015

\begin{tabular}{|c|l|l|l|l|l|l|l|}
\hline \multirow{2}{*}{ No } & \multirow{2}{*}{ Countries } & \multicolumn{3}{|l|}{ Fisheries (tons) } & \multicolumn{3}{l|}{ Aquatic Plants (tons) } \\
\cline { 3 - 8 } & & Capture & Aquaculture & Total & Capture & Aquaculture & Total \\
\hline 1 & China & $17,591,299$ & $47,610,040$ & $65,201,339$ & 261,770 & $13,924,535$ & $14,186,305$ \\
\hline 2 & Japan & $3,460,168$ & 703,915 & $4,164,083$ & 93,300 & 300,300 & 393,600 \\
\hline 3 & South Korea & $1,648,993$ & 479,360 & $2,128,353$ & 7,826 & $1,197,129$ & $1,204,955$ \\
\hline 4 & North Korea & 220,000 & 64,150 & 284,150 & - & 489,000 & 489,000 \\
\hline 5 & Indonesia & $6,485,320$ & $4,342,465$ & $10,827,785$ & 78,230 & $11,269,341$ & $11,347,571$ \\
\hline 6 & Malaysia & $1,491,974$ & 246,205 & $1,738,179$ & - & 260,760 & 260,760 \\
\hline 7 & Philippines & $2,151,502$ & 781,798 & $2,933,300$ & 367 & $1,566,361$ & $1,566,728$ \\
\hline 8 & Vietnam & $2,757,314$ & $3,438,378$ & $6,195,692$ & & 11,822 & 11,822 \\
\hline 9 & Thailand & $1,693,050$ & 897,096 & $2,590,346$ & - & 934,800 & 934,800 \\
\hline 10 & Singapore & 1,645 & 4,971 & 6,616 & - & - & - \\
\hline 11 & Brunei & 4,000 & 711 & 4,711 & - & - & - \\
\hline 12 & Myanmar & $1,953,510$ & 997,306 & $2,950,816$ & & 2,324 & 2,324 \\
\hline 13 & Cambodia & 639,468 & 120,055 & 759,523 & - & - & - \\
\hline
\end{tabular}

Source: FAO (2017), World Fisheries and Aquaculture Production

The second notion about the importance of Asia-Pacific maritime area is that the South China Sea and the Strait of Malacca are not only important for their marine outcomes, but also for their strategic position in connecting states and for its SLOCs. This is to confirm that the South China Sea, passing the Strait of
Malacca, is significant for transportation and connectivity as well as trading system. Stretching from Singapore and the Strait of Malacca chokepoint in the southwest to the Strait of Taiwan in the northeast, the South China Sea is one of the most important energy trade routes in the world. The United Nations Conference 
on Trade and Development (UNCTAD) confirmed that in 2013 approximately 30\% of the world's sea-based trading (UNCTAD, 2013) and nearly $60 \%$ of oil products and global liquefied natural gas (LNG) traveled from the Strait Hormuz and Strait of Malacca to South China Sea (U.S. EIA, 2013).

The report from U.S. EIA (2013) also justified that more than 15 million barrels oil per day flowed from the Persian Gulf, through the Strait of Malacca and South China Sea, to East Asian countries as well as the U.S. In comparison, the world's most important chokepoint for maritime transit, the Strait of Hormuz between the Persian Gulf and Arabian Sea, had an oil flow of about 17 million barrels per day in 2011. The number of 15 million barrels per day significantly increased from the last two decades. In 1993, according to the Center for Naval Analysis, about 7 million barrels per day of oil and petroleum products, which was equivalent to $20 \%$ of world seaborne oil trade, passed through the Strait of Malacca. Moreover, the Strait of Malacca plays important role since it is the main entrance and the shortest sea route from the Persian Gulf to East Asia.

However, the globalized maritime area not only endows states with increase in economic development, but also triggers transnational organized crimes, which mainly happen at sea. Thachuk and Tangredi (2002) define transnational organized crimes as crime activities perpetrated by non-state actors that not only go beyond national borders but also have global impact. They distinguish transnational crime perpetrators into two types of non-state actors, namely terrorist groups and organized criminal groups. With regards to terrorist groups, their activities nowadays are more intensely carried out, publicly targeted, and globally directed. They also use the same methods conducted by organized crime groups to finance their organizations, such as drugs trafficking, arms smuggling, money laundering, human trafficking, and piracy. In the case of maritime AsiaPacific, terrorist attacks have become an issue since some Southeast Asian states have to deal with radical and terrorist groups, such as Indonesia, Thailand, and the Philippines.

In relation to piracy threats, as reported by the International Chamber of Commerce's International Maritime Bureau (ICC-IMB), there were 576 pirate attacks in the Strait of Malacca, Singaporean, Indonesian, and Malaysian coastal waters in 2004-2009 (ICC-IMB, 2004-2009), nearly $36 \%$ of all piracy attacks in all seas around the world. However, the ICC-IMB in 2011 reported that the number of piracy crimes in the Strait of Malacca, Singapore, Indonesian, and Malaysian coastal waters had dropped into 240 attacks in 2007-2010 (ICC-IMB, 2007-2009). This might have happened because the littoral states Indonesia, Malaysia, and Singapore - had conducted joint patrols to protect the Strait of Malacca since July 2005. Despite the joint patrols, the piracy numbers increased into 631 incidents in 2010-2015 (ICC-IMB, 2010-2015). The increasing number of pirate attacks off the coast of Indonesia, Strait of Malacca, Malaysia, and Singapore Strait confirms the need of ASEAN littoral states to protect the security of their waters.

To assure the free flow of goods and to safeguard the oil and petroleum supply, as well as to protect marine productions and sea territory, Asia-Pacific states continuously develop their naval power. Along with the increase of 
economic prosperity, some states in the region are modernizing their military power and enhancing their military budget. As China's 2015 Defense White Paper confirms that the threats for China's maritime areas surely come from state and non-state actors, the Chinese government plans to gradually shift its People's Liberation Army Navy (PLAN)'s focus from "offshore waters defense" to the combination of "offshore waters defense" with "open seas protection". As its economy has grown over the last decade, the Chinese authority allows PLAN to build a combined, multi-functional, and efficient marine combat force structure. This is to conclude that PLAN will enhance its capabilities for strategic deterrence and counterattack, maritime maneuvers, joint operations at sea, comprehensive defense, and comprehensive support.

However, PLAN modernization and an increase in China's military spending with the justification of its security and defense have provoked similar reaction from the unhappy, threatened neighbors. The lack of navies' arrangement coupled with their naval capacities in the region has also become another concern, as there is no mechanism to supervise the naval power development of Asia-Pacific states. Regarding this, Rousseau argues that the weak position of one's military power increases the perception of threat that leads to security dilemma and military competition $(\mathrm{Ng}, 2005)$. In turn, military competition, as noted by Stephen Walt (1987), may trigger military alliances as states' response to threats and attempt to prevent stronger powers from dominating them. This situation accordingly intensifies the tension amongst AsiaPacific states. This is true as in the case of Japan, Vietnam, and the Philippines that have conducted joint military exercises with the U.S. as they have problem with China in their overlapping claims on the East and South China Sea.

Eventually, the importance of South China Sea and the Strait of Malacca for sea-based trading system and SLOCs as well as the increasing number of transnational crimes endangering the economic prosperity in Asia-Pacific states have become common concerns mainly for Asia-Pacific states. This is not to mention the instability in the region due to arms dynamic. Their common concerns are derived from the willingness to maintain their national economic development as well as regional security and stability. For this reason, major powers in Asia-Pacific and Southeast Asia such as the U.S., China, and Indonesia have launched their strategies either to safeguard their water territories and interests or to guarantee their access through the waters.

In front of the Asia-Pacific leaders during East Asia Summit in November 2011, U.S. President Obama initially explained the U.S. rebalancing strategy in Asia-Pacific to secure and protect their vital interest in the region. To reflect his intention, the U.S. 2012 Defense Strategic Guidance justifies the U.S. military to continue their leadership in promoting stability and security regionally and globally by building stronger partnership with capable allies. According to U.S. authorities, the aim of this partnership is to reassure that the presence of U.S. military personnel and capability in the region is to maintain peace and stability collaboratively, as well as to safeguard the access and the use of global commons through seas. The partnership is not only of the U.S. interest, but also of Asia-Pacific states' interests (U.S. DoD, 2012). 
This strategy continues under the Trump administration. The U.S. remains focused on the growing importance of the region, particularly for its seas and the freedom of navigation operations. The American Defense Chief, Secretary Mattis outlines the U.S. effort to achieve a rebalance to the Asia Pacific region. Some of the efforts are to strengthen alliances, encourages strong and responsible partners and strengthen U.S military capabilities in the region. Those are in addition to less formal networked security cooperation or interconnected region, to include bilateral, trilateral and multilateral exchanges, exercises and arms transfers. (Cronin, 2017)

As a response to the U.S. initiative in the maritime Asia-Pacific, which partly is also performed by joint military operations, China has launched its counter-balance strategy. Since Chinese government is still locked in sea border disputes with Japan and four of ASEAN members - Vietnam, the Philippines, Brunei Darussalam, and Malaysia Chinese President $X_{i}$ Jinping firmly declared his disapproval of the involvement of external powers, mainly the U.S. In the 2014 Conference on Interaction and Confidence-Building Measures in Asia (CICA), President $\mathrm{Xi}$ Jinping proposed a new "Asian Security Concept" which argues that Asian problems should be resolved by Asian people and that Asian security should be protected by Asian people: “...it is for the people of Asia to run the affairs of Asia, solve the problems of Asia and uphold the security of Asia. The people of Asia have the capability and wisdom to achieve peace and stability in the region through enhanced cooperation" (Xi, 2014).

Previously, in September 2013, the Chinese authorities also proposed a framework and cooperation mechanism to bring China, Central Asia, Russia, and Europe, as well as Southeast Asia together to build "Silk Road Economic Belt and the $21^{\text {st }}$ century Maritime Silk Road". With regards to Southeast Asian countries, in front of Indonesian parliament members in October 2013, President Xi stated the Chinese government's initiative to finance infrastructure construction and promote regional interconnectivity and economic integration by establishing the Asian Infrastructure Investment Bank (AIIB). This initiative is particularly focused on the China-ASEAN maritime partnership, with the basis of mutual trust and goodneighborliness, win-win cooperation, togetherness, mutual understanding and friendship, openness, and inclusiveness (Xi, 2013).

Similarly, the newly elected Indonesian President Joko Widodo declared his intention to bring Indonesia to become the Global Maritime Fulcrum at his first speech before East Asian leaders in November 2014 (The Jakarta Post, 2014). The Fulcrum consists of five components, which are: (1) rebuilding the Indonesia's maritime culture, (2) maintaining and managing marine resources, (3) developing maritime infrastructure and connectivity, enhancing maritime diplomacy, and (5) developing maritime defense forces. With the fact that Indonesia lies strategically between the Indian and Pacific Oceans passing the Strait of Malacca and South China Sea, Jokowi's Global Maritime Fulcrum doctrine shortly provoke China and the U.S. to approach Indonesia. Both countries are proposing comprehensive strategic partnership with Indonesia particularly in maritime cooperation (The Jakarta Post, 2014). 
The U.S., China, Indonesia, and other ASEAN member states' respective maritime strategies are likely to provoke mutual contention in the region. Yet, their various policies also show their common concerns with regards to their maritime territories as well as regional security and stability. Despite their different stances and capabilities regarding the issue of East and South China Sea management, all countries in the region believe that cooperation is vital in maintaining regional as well as global peace, prosperity, security, and stability. The abundance of natural resources including fisheries, oil, and gas reserves coupled with the need to secure their SLOCs and sea trading system in AsiaPacific waters from both traditional and non-traditional threats have called these states for cooperative management on such common concerns. From their defense white papers, we can conclude that ASEAN member states as well as the U.S. and China express their needs for a cooperative and comprehensive integrated action as well as a series of confidence-building measures and selfrestraint in achieving mutual interests.

\section{The Role of ASEAN and Challenges}

ASEAN, as one of regional associations in the Southeast and East Asia regions whose aim is to promote regional peace, prosperity, and stability, has a great opportunity to facilitate and accommodate its member states' interests on one hand and external powers' interest on the other hand in such collaborative way. Although ASEAN was initially established to enhance the economic, social, and cultural cooperation among its members as written in its 1967 Bangkok Declaration, security has greatly remained at the core of its existence (Severino, 2006). Indeed, former Singaporean Prime
Minister Lee Kuan Yew also mentions in his memoirs that in its development, ASEAN was banding together more for political objectives, stability, and security (Lee, 2000). His statement is true as in the case of South China Sea dispute.

As a contending issue between China and four ASEAN members Vietnam, the Philippines, Malaysia, and Brunei Darussalam - South China Sea overlapping claims have threatened the regional peace and stability as well as the economic development. In the name of protection of sea territory and natural resources from both traditional and nontraditional threats, claimant states subsequently enhance their naval activities. Moreover, the Chinese government's rejection against the decision of international tribunal regarding the case of South China Sea arbitration brought by the Philippines seemingly failed to resolve the problem on the legal basis. At this point, ASEAN should play its central role in maintaining security and stability in the region.

ASEAN has actually put its effort to discuss the issue in many summits and dialogues. The first workshop initiated by Indonesia was conducted in 1990 to manage potential conflict in the South China Sea. Afterwards, the issue of South China Sea and its management has been discussed every year in ASEAN leaders' joint communiqués and chairmen's statements. In 1992, ASEAN as a united posture eventually succeeded to bring China to sign the Declaration on the South China Sea, and then followed by the 2002 Declaration on the Conduct of Parties in the South China Sea (DOC). Both agreements essentially called for a peaceful resolution of jurisdictional disputes by peaceful means without resorting to force, the exercise of self- 
restraint, possible cooperation in maritime safety, marine environmental protection, search and rescue operation, action against transnational crimes, and the application of the principles of the Treaty of Amity and Cooperation as the basis for a code of conduct for the South China Sea dispute. This was also to confirm that ASEAN had become a primary driving force institution that was responsible to maintain peace, prosperity, security, and stability, particularly in Southeast Asia and Asia-Pacific region.

With regard to its responsibilities in maintaining peace, stability, and security in the region, ASEAN also has several mechanisms where all members may have dialogue and consultation on common political and security issues, as well as significantly contribute towards confidence building and preventive diplomacy. Such mechanism is implemented in the ASEAN Regional Forum (ARF), ASEAN Defence Ministers' Meeting (ADMM), and ADMM-Plus Australia, China, India, Japan, New Zealand, South Korea, Russia, and the U.S. as ASEAN counterparts. They are complement to the ASEAN Maritime Forum (AMF) and Expanded ASEAN Maritime Forum (EAMF). In these forums, ASEAN member states and their counterparts conduct dialogues on defense and security issues, and the latter is particularly for maritime issues.

Such dialogues and security mechanisms are effective to build the confident between ASEAN members and its counterparts. Nevertheless, during the 2012 ASEAN Summit in Cambodia the ASEAN leaders, for the first time, failed to reach an agreement on how to manage the South China Sea dispute. The debate continued as during the 2015 ADMM-Plus forum, the ASEAN counterparts including
Australia, China, India, Japan, and the U.S. also failed to reach a declaration on the same issue (Reuters, 2015). Besides, a prolonged processed of South China Sea Code of Conduct are of signals that the division amongst ASEAN members regarding South China Sea management remains problematic. The partnership of ASEAN member states with different counterparts in Asia-Pacific as described in Table 2 is very likely to exacerbate the disunity of ASEAN.

From the table below, we can see that almost all ASEAN countries have made their respective bilateral and/or multilateral agreements on economic, defense, and maritime issues with various external partners such as the U.S., China, and Japan. Indonesia, Malaysia, the Philippines, Singapore, and Thailand for example have maritime cooperation and military exercise in the Exercise RIMPAC with the U.S., Australia, Japan, Korea, New Zealand, India, Canada, and the UK, without China and other ASEAN member-states in it. In trade, investment, and economic, Brunei Darussalam, Malaysia, Singapore, and Vietnam are in cooperation with Australia, Japan, and Canada in Trans-Pacific Partnership (TPP)-11, whereas Myanmar, Cambodia, Indonesia, Laos, Philippines, and Thailand prefer to join the Regional Comprehensive Economic Partnership (RCEP) with China in the scheme. These partnerships contribute positively to ASEAN countries' economic development and security, but also provoke contention and competition at the same time due to clash of their and their partners' interests.

Interestingly, the East Asian Summit (EAS) in November 2015, couple weeks after the ADMM-Plus, prevailed to launch a joint statement on Enhancing Regional Maritime Cooperation. This 
statement confirmed the centrality role of ASEAN and ASEAN-led mechanisms in maintaining the peace, stability, safety, and security in the region, particularly at its seas and oceans. This was also to confirm that both ASEAN and major powers in Asia-Pacific needed to realize the establishment of Regional Maritime Strategic Partnership and Cooperation, in which ASEAN becomes the primary driving force. This regional maritime strategic partnership can be an initial step for South China Sea dispute management.

The Regional Maritime Strategic Partnership and Cooperation launched in November 2015 mainly discussed on comprehensive issues focusing on safety of navigation and sea dispute management as a way for confidence buildings measures. In further steps, the forum should also harmonize the diverse interests and make into realization of the regional maritime cooperation including activities such as information sharing; technological cooperation; exchange of visits of related authorities; maritime connectivity and capacity building; infrastructure and equipment upgrading; seafarers' training; marine-science research; marine environment protection; eco-tourism promotion; disaster relief; illegal, unreported, and unregulated (IUU) fishing countermeasures; illicit small arms; drugs trafficking; and people smuggling combat; as well as security at sea and ports.

Table 2. ASEAN Countries' Partnerships

\begin{tabular}{|c|c|c|c|}
\hline Partnership & ASEAN Countries & ASEAN Counterparts & Area of Cooperation \\
\hline $\begin{array}{l}\text { Rim of the Pacific } \\
\text { Exercise (RIMPAC) }\end{array}$ & $\begin{array}{lr}\begin{array}{l}\text { Indonesia, } \\
\text { Philippines, } \\
\text { and Thailand }\end{array} & \text { Singapore, } \\
\end{array}$ & $\begin{array}{l}\text { The U.S., Australia, Japan, } \\
\text { Korea, New Zealand, India, } \\
\text { Canada, Chile, Colombia, } \\
\text { France, Norway, Peru, Mexico, } \\
\text { Netherlands, Tonga, and the } \\
\text { U.K. }\end{array}$ & $\begin{array}{l}\text { Maritime and military } \\
\text { exercises }\end{array}$ \\
\hline $\begin{array}{l}\text { Trans-Pacific } \\
\text { Partnership (TPP) - } \\
11\end{array}$ & 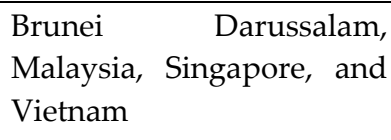 & $\begin{array}{l}\text { Australia, Canada, Japan, New } \\
\text { Zealand, Chile, Mexico, and } \\
\text { Peru }\end{array}$ & $\begin{array}{l}\text { Trade, investment, and } \\
\text { economic }\end{array}$ \\
\hline $\begin{array}{l}\text { Regional } \\
\text { Comprehensive } \\
\text { Economic } \\
\text { Partnership (RCEP) }\end{array}$ & 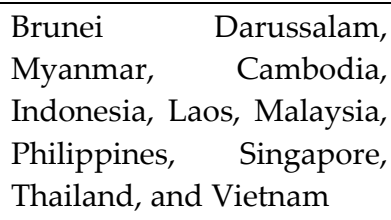 & $\begin{array}{l}\text { Australia, China, India, Japan, } \\
\text { South Korea, and New Zealand. }\end{array}$ & $\begin{array}{l}\text { Trade, investment, and } \\
\text { economic }\end{array}$ \\
\hline $\begin{array}{l}\text { Asia-Pacific } \\
\text { Economic } \\
\text { Cooperation (APEC) }\end{array}$ & $\begin{array}{lr}\text { Brunei, } & \text { Indonesia, } \\
\text { Malaysia, } & \text { Philippines, } \\
\text { Singapore, Thailand, and } \\
\text { Vietnam }\end{array}$ & $\begin{array}{l}\text { Australia, Canada, Japan, South } \\
\text { Korea, New Zealand, the U.S., } \\
\text { China, Mexico, Papua New } \\
\text { Guinea, Chile, Peru, and Russia }\end{array}$ & $\begin{array}{l}\text { Economic, free trade } \\
\text { agreement proposal }\end{array}$ \\
\hline $\begin{array}{l}\text { East Asian Summit } \\
\text { (EAS) }\end{array}$ & $\begin{array}{l}\text { Brunei, } \\
\text { Indonesia, Laos, Malaysia, } \\
\text { Myanmar, } \quad \text { Philippines, } \\
\text { Singapore, Thailand, and } \\
\text { Vietnam }\end{array}$ & $\begin{array}{l}\text { Australia, China, India, Japan, } \\
\text { New Zealand, Russia, South } \\
\text { Korea, and the U.S. }\end{array}$ & $\begin{array}{l}\text { Forum to discuss } \\
\text { economic cooperation, } \\
\text { energy, climate change, } \\
\text { and internal ASEAN } \\
\text { issues. }\end{array}$ \\
\hline
\end{tabular}


With such scope of cooperation, a regional maritime strategic partnership is important to enhance stability in the region. There are at least three reasons why ASEAN member states need to realize this regional maritime partnership. First, it strengthens mutual trust amongst ASEAN countries, as it will be a mechanism in which ASEAN countries speak as one united actor. Second, the partnership builds common perception between ASEAN countries and its counterparts in Asia-Pacific, particularly with China regarding the South China Sea management. Eventually, with mutual trust and common concern between all parties, the partnership gradually reduces the tension in the region relating to South China Sea issue and other maritime managements, as they will collaboratively resolve the problems, both traditional and nontraditional challenges.

Nevertheless, this regional maritime partnership can be a test case for ASEAN unity and centrality. As a regional organization, ASEAN's main task is to accommodate its diverse member states' interests and capabilities. Moreover, as a unified actor in the region, ASEAN needs to harmonize its member states' interest with external powers' interest. It is complicated for ASEAN especially after experiencing its first years of ASEAN Community. In such case, ASEAN member states need to build a common perception amongst them related to conflicting issues with a basis that they have common concern on the same issues. Besides, as an organization, ASEAN needs to ensure that its member states' respective bilateral and/or multilateral cooperation do no harm to other ASEAN member states' interests.

\section{Conclusion}

The importance and vulnerability of Southeast and East Asia region, coupled with its maritime security, has urged major powers in the region to launch their respective maritime and defense strategies which are important to promote national prosperity and security as well as regional stability. As a united actor in the region, ASEAN should also play its role according to its responsibilities by looking at common concerns of its members and counterparts. With regards to the South China Sea issue, ASEAN has conducted some internal mechanisms to resolve the problem, yet it failed to achieve an agreement on the issue. However, external ASEAN-led mechanisms can be utilized to resolve the sea dispute. To speak as one united actor, ASEAN should perform its leadership and centrality in Regional Maritime Partnership and Cooperation, involving other pacific states and ASEAN counterparts, mainly China, South Korea, Japan, Australia, New Zealand, and the U.S. By this, ASEAN needs more confidence-building measures to build common perception with common concern amongst its member states and to ensure its member states get no harm from their respective bilateral and/or multilateral partnership with external powers.

\section{About the Author}

The writer is lecturer and senior researcher at the Center for Security and Foreign Affairs Studies, International Relations Program, Faculty of Social and Political Science, Christian University of Indonesia. 


\section{References}

ASEAN. (n.d.). The 2002 ASEAN Declaration on the Conduct of Parties of South China Sea. Retrieved on June 24, 2016 from

http://www.asean.org/asean/externa 1-relations/china/item/declarationon-the-conduct-of-parties-in-thesouth-china-sea.

ASEAN. (2015). EAS Joint Statement on Enhancing Regional Maritime Cooperation. Retrieved on June 24, 2016 from http://www.asean.org/storage/image s/2015/November/10th-EAS-

Outcome/EAS\%20Statement\%20on \%20Enhancing\%20Regional\%20Mari time\%20Cooperation $\% 20$ \%20FINAL $\% 2022 \% 20$ November $\% 20$ 2015.pdf.

Bennett, A., \& Elman, C. (2006). Complex causal relations and case study methods: The example of path dependence. Political analysis, 14(3), 250-267.

Bennett, A., \& Elman, C. (2007). Case study methods in the international relations subfield. Comparative Political Studies, 40(2), 170-195.

Bisnis Tempo.co. (2014). Menteri Susi tangkap 22 Kapal China. Retrieved on June 28, 2016 from http://bisnis.tempo.co/read/news/20 14/12/08/090627197/menteri-susitangkap-22-kapal-ikan-cina.

Bradford, J. F. (2011). The maritime strategy of the United States: implications for Indo-Pacific sea-lanes. Contemporary Southeast Asia: A Journal of
International and Strategic Affairs, 33(2), 183-208.

Centre for International Law - NUS. (n.d.). The 1992 ASEAN Declaration on the South China Sea. Retrieved on June 24, 2016 from http://cil.nus.edu.sg/rp/pdf/1992\%20 ASEAN\%20Declaration\%20on\%20th e\%20South\%20China\%20Seapdf.pdf.

Centre for International Law - NUS. (2011). Documents on ASEAN and South China Sea. Retrieved on June 26, 2016 from http://cil.nus.edu.sg/wp/wpcontent/uploads/2011/06/Documents -on-ASEAN-and-South-China-Seaas-of-June-2011.pdf.

CNN Indonesia. (2015). Menteri Susi tangkap 16 kapal asing sepanjang September 2015. Retrieved on June 28, 2016 from

http://www.cnnindonesia.com/politi k/20151002133734-32-82341/menterisusi-tangkap-16-kapal-asingsepanjang-september-2015/.

Cronin, Patrick M., (2017). “The US Naval Buildup and Asia under the Trump Administration." Retrieved on April 12, 2018 from http://www.maritimeissues.com/usnew-administration/the-us-navalbuildup-and-asia-under-the-trumpadministration.html

FAO Fisheries \& Aquaculture. (2011). Statistics. (2013). Retrieved in June, 24, 2016 from http://www.fao.org/fishery/statistics len.

FAO Fisheries \& Aquaculture. (2013). World 
Fisheries Production, by Capture and Aquaculture. Retrieved on October 24, 2016 from ftp://ftp.fao.org/FI/STAT/summary/a -0a.pdf.

FAO. (2016). The State of World Fisheries and Aquaculture: Contributing to Food Security and Nutrition for All, Rome.

FAO. (2017). World Aquaculture 2015: A Brief Overview. FIAA/C1140. Rome

ICC-ICS. (2015). Maritime Piracy Reports. Retrieved on June 28, 2016 from https://www.icc-ccs.org/news/1111maritime-piracy-report-revealscontinued-se-asian-attacks-againstsmall-tankers.

ICC-IMB. (2004). Piracy and Armed Robbery Against Ships.

ICC-IMB. (2005). Piracy and Armed Robbery Against Ships.

ICC-IMB. (2006). Piracy and Armed Robbery Against Ships.

ICC-IMB. (2007). Piracy and Armed Robbery Against Ships.

ICC-IMB. (2008). Piracy and Armed Robbery Against Ships.

ICC-IMB. (2009). Piracy and Armed Robbery Against Ships.

ICC-IMB. (2010). Piracy and Armed Robbery Against Ships.

ICC-IMB. (2011). Piracy and Armed Robbery Against Ships.

ICC-IMB. (2012). Piracy and Armed Robbery Against Ships.
ICC-IMB. (2013). Piracy and Armed Robbery Against Ships.

ICC-IMB. (2014). Piracy and Armed Robbery Against Ships.

ICC-IMB. (2015). Piracy and Armed Robbery Against Ships.

Jervis, R. (1976). Perception and misperception in international politics. Princeton University Press.

Kegley, C. W., \& Wittkops, E. R. (2001). World Politics: Trend and Transformation. Bedford.

Lee, K. Y. (2000). From third world to first: The Singapore story, 1965-2000. Times Media Private Limited.

Mahoney, J., \& Goertz, G. (2006). A tale of two cultures: Contrasting quantitative and qualitative research. Political analysis, 14(3), 227249.

Ministry of National Defense, People's Republic of China. (2015). Chinese Military Strategy. Retrieved on June 26, 2016 from http://eng.mod.gov.cn/Database/Wh itePapers/.

$\mathrm{Ng}$, K. P. (2005). Interpreting China's military power: doctrine makes readiness. Routledge.

Politik Indonesia. (2015). Indonesia kerepotan Berantas Illegal Fishing. Retrieved on June 28, 2016 from http://www.politikindonesia.com/in dex.php?k=wawancara\&i=55554Ida-Kusuma-Wardhaningsih:$\underline{\text { Indonesia-Kerepotan-Berantas- }}$ Illegal-Fishing. 
Prabhakar, W. L. S. (2006). Maritime Strategic Trends in the Asia-Pacific: Issues and Challenges. In The Evolving Maritime Balance of Power in the Asia-Pacific: Maritime Doctrines and Nuclear Weapons at Sea (pp. 3568). Institute of Defence and Strategic Studies.

Reuters. (2015). ASEAN Defense Chiefs Fail to Agree on South China Sea Statement. Retrieved on June 24, 2016 from http://www.reuters.com/article/2015 11/04/us-asean-malaysia-statementidUSKCN0ST07G20151104\#owkWX SsCfiTQDh0w.99.

Severino, C. R. (2006). Southeast Asia in search of an ASEAN community: Insights from the former ASEAN secretary-general. Institute of Southeast Asian Studies.

Subangsinghe, Rohana. (2017). Regional Review on Status and Trends in Aquaculture Development in Asia Pacific - 2015, FAO Fisheries and Aquaculture Circular No. 1135/5, Rome, Italy.

Thachuk, K., \& Tangredi, S. (2002). Transnational threats and maritime responses. Globalization and maritime power. National Defense University.

The Diplomat. (2015). Global Maritime Fulcrum and the US-Indonesia Partnership. Retrieved on June 28, 2016 from http://thediplomat.com/2015/10/how -the-global-maritime-fulcrum-canelevate-the-us-indonesiapartnership/.

The Jakarta Post. (November 13, 2014).
Jokowi Launches Maritime Doctrine to the World. Retrieved on June 28, 2016 from http:// http://www.thejakartapost.com/new s/2014/11/13/jokowi-launchesmaritime-doctrine-world.html.

The White House. (2011). Fact Sheet: East Asia Summit. Retrieved on June 30, 2016 from http://www.whitehouse.gov/thepress-office/2011/11/19/fact-sheeteast-asia-summit.

Till, G. (2009). Seapower. A Guide for the Twenty First Century. Routledge.

UNCTAD. (2013). Review of Maritime Transport. Retrieved on October 30, 2016 from http://unctad.org/en/PublicationsLib rary/rmt2013 en.pdf.

U.S. DoD. (2012). Sustaining US Global Leadership: Priorities for 21 ${ }^{\text {st }}$ Century Defense. Retrieved on June 28, 2016 from

http://archive.defense.gov/news/Def ense Strategic Guidance.pdf.

U.S. EIA. (2013). South China Sea Overview. Retrieved on June 24, 2016 from http://www.eia.gov/beta/internation al/analysis includes/regions of inte rest/South China Sea/south china s ea.pdf.

U.S. EIA. (2014). World Oil Chokepoints. Retrieved on June 28, 2016 from. http://www.eia.gov/beta/internation al/analysis includes/special topics/ World Oil Transit Chokepoints/wo tc.pdf.

Walt, S. (1987). The Origins of Alliances. 
Cornell University Press.

$\mathrm{Xi}$, Jinping. (2013). Speech to Indonesian Parliament. Retrieved on June 24, 2016 from http://www.asean-chinacenter.org/english/201310/03/c 133062675.htm.

Xi, Jinping. (2014). New Asian Security Concept For New Progress in Security
Cooperation. Retrieved on June 24, 2016 from http://www.fmprc.gov.cn/mfa eng/z xxx 662805/t1159951.shtml.

Xinhua. (2015). Chronology of China's Belt and Road Initiative. Retrieved on June 26, 2016

from http://news.xinhuanet.com/english/2 015-03/28/c 134105435.htm. 